\title{
Multicultural Learning Styles Dilemma: Re-Thinking Management Education
}

\section{Syed Raza Ali Bokhari}

Bahria University, Pakistan

razaphd@gmail.com

\section{Doi:10.5901/jesr.2014.v4n6p373}

\section{Introduction}

In this era of globalization, businesses pursue strategic advantage by shifting from being multinational to being transnational organizations. The idea of globalization represents an ever changing process that brings people and societies together into a common market of not only goods and services but also knowledge. Business curricula must also change to face this new and changed world. Arguably, business education focuses on presenting scientific principles by objectifying theories and their applications, essentially homogenizing them. However, business theories being universal are applied in various cultural contexts with varied results, and with various accreditation agencies standardizing the MBA program, homogenization is insured without regard to when, where, how and why it is applied. This thinking may be faulty. A realistic explanation for rejection of homogeneity is due to multifaceted cultural factors and contexts in which business is practiced. This apparent rejection of homogeneity is further evidenced when according to (Hooker, 2003, p. 13), "...global business and media weaken the nation state and the civic institutions it represents by making them increasingly irrelevant. More ancient forms of social organization fill the void, as nation states fracture along ethnic and religious lines." Students may defocus themselves from real implications of understanding and subsequent application of various business theories, especially if they are out of cultural context. While numerous cross cultural studies have surfaced focusing on national culture, there has been little or no attempt to unveil the impact of ethnic culture on learning.

\section{Culture}

Research on culture spans many disciplines such as Anthropology (Benedict, 1946); (Hall, 1977); (Kluckhohn, 1962); Psychology (Markus \& Kitayama, 1991); (Triandis, 1994) and Management (Hofstede, 2001) (House, Hanges, Javidan, Dorfman, \& Gupta, 2004). Research scholars have come to more or less a common ground with respect to defining culture. For instance, (House et al., 2004, p. 15) stipulated that culture can be conceptualized as "shared motives, values, beliefs, identities, and interpretations or meanings of significant events that result from common experiences of members of collectives that are transmitted across generations". Moreover, (Spencer-Oatey, 2000, p.4) notion that culture is "a fuzzy set of attitudes, beliefs, behavioral conventions and basic assumptions and values that are shared by a group of people and that influence each member's behavior and their interpretation of the meaning of other people's behavior". Culture can thus be seen as deep rooted, multi-faceted and dynamic, dependent on interaction with contextual variables. It can, therefore, be argued that even though groups may present with similar attitudes and beliefs but these will not be homogeneous and there will be overlap between one's different cultural sets at an individual (micro) and societal (macro) level. Nonetheless, (Mitchell, Xu, Jin, Patten, \& Gouldsborough, 2009) and (Mitsis \& Foley, 2009) demand that further research be conducted in exploring the ways in which individuals navigate specific contexts across cultures and disciplines since evidently influence of culture in determining learning behaviors and style preferences exists.

\section{Cultural Complexity}

(Hofstede \& Hofstede, 2005) acknowledge this with their notion of 'cultural software' and its role as a filter in terms of how individuals process information. In addition, it has been evidenced by (Signorini, Wiesemes, \& Murphy, 2009) that cultural variables impact on how students evaluate teaching and their beliefs about learning. Therefore, it may be reasonable to expect that culture also impacts on how individuals perceive and act on feedback particularly, given that culture, 
communication and learning are interweaved. Humans are often characterized as complex machines with built in software called genes. Culture is, therefore, the collective programming of the mind which differentiates members of one group of people from another. Culture is not inherited rather learned, and emanates from one's social environment, not from one's genes. This is evidenced from the fact that almost everyone belongs to a number of different ethnic groups and categories of people at the same time, people inescapably carry several layers of mental programming within themselves, corresponding to different levels of culture. For example, various forms of culture may be prevalent in a given country such as national, regional, ethnic, religious, social class, occupation, profession, and corporate etc.

(Shi, 2004) draws attention to the significant changes that some Asian educational systems have gone through recently and how these are not addressed in the literature. Hofstede's model revolves strictly around measuring national cultural difference. While considerable variation was found in responses of fellow countrymen, the model does not account for these, that is, Hofstede creates cultural uniformity through his use of averages. This is heightened by (Hofstede, 1986) suggestions that the model be used as an analytical tool to understand students' experiences. This result in producing constructs of national students, for example, 'the Chinese learner'. However, (Gu \& Maley, 2008) and (Kennedy, 2002) argue against using categories such as 'the Chinese learner', as it implies that this group of learners are a homogeneous group, whilst ethnicity, gender, age and location differences are ignored. The same argument holds for other types of national learners. Researchers, such as (Cambridge, 2006) and (Kingston \& Forland, 2004) in the field of education, (Baskerville, 2003) and (Williamson, 2002) in the field of management have been critical of Hofstede's tendency to equate culture to nationality. Thus, due to diversity and multi-faceted ethnic backgrounds, it may be argued that there may be cultural learning styles differences within the country and among various ethnic groups.

\section{Learning and Culture}

Experiential learning theory developed by (Kolb, 1984), is based on the work of notable 20th century scholars such as John Dewey, Kurt Lewin, Jean Piaget, William James, Carl Jung, Paulo Freire, Carl Rogers and others, who visualized experience as having an integral and central role in their theories of learning and development. The Kolb's model which is based on the Scientific Method theory, as explained in his book Experiential Learning: Experience as the source of learning and development (Kolb, 1984). According to (Kolb, 1984: 41) "Learning is the process whereby knowledge is created through the transformation of experience. Knowledge results from the combination of grasping experience and transforming it". Experiential Learning Theory (ELT) model sketches two related approaches toward grasping experience: Concrete Experience and Abstract Conceptualization, as well as two related approaches toward transforming experience: Reflective Observation and Active Experimentation. Figure 1 depicts Kolb's ELT model.

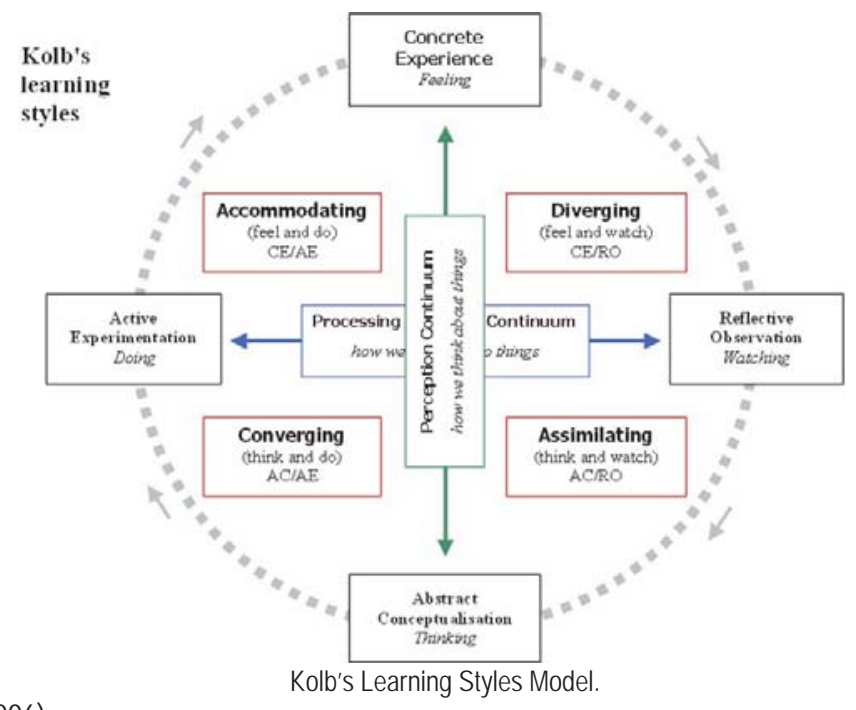

Source: (Chapman, 2006)

According to Kolb's model, learning process employs all four of these modes in response to a given situation, and for 
learning to be effective, all four of these approaches must be incorporated.

Culture and learning go hand in hand so far as to say it may be unimaginable to remove a cultural bias in the learning process. While human beings tend to be social in nature, culture acts as a robust socialization and bonding agent that impacts information processing and cognition. Thus, differences in cultural socialization coupled with environmental factors may tend to influence learning styles and culture. Pakistani education system serves as a perfect example where standardized education remains a myth. The spectrum of education services is at two extremes. On one hand, most modern education based on International standards is being imparted; on the other hand, children study in substandard school buildings with little or no academic resources. Given this scenario, influence on thinking and behavior can be seen as existing at several levels, including human nature, culture, and personality. Culture embraces those ways of thinking and behaving that are taught by society, friends, families, and media. Among many other things, culture includes how people interact among themselves, the way they think, how they move, how problems are solved, how their living environment and government is structured. Pakistan, with its four provinces having distinct multilingual ethnic groups poses a real challenge to the cultural learning styles theory. Curriculum at the MBA level entails books written by foreign authors; hence, apart from being contextually different, illustrations, examples, and cases quoted to explain a particular concept are of such organizations to which students are completely oblivious. Influence of culture tends to prevail no matter how structured a curriculum may become in accord with accrediting bodies and established standards. As an example, a Swedish professor of management will implicitly integrate Swedish social constructs and culture into his/her teaching of business management courses, thereby, potentially altering the context of the standard. Similarly, an American professor implicitly integrates philosophies of American business culture with respect to American markets in the context of an objective standard.

\section{Literature Review}

Having established the relationship of culture with learning styles, recently, (Moskvina, Kozhevnikov, Rayner, \& Cools, 2011) have highlighted the need to consider the interrelationships between individuals' patterns of information processing and their immediate surroundings, educational systems, social groups, professional environments as well as the global cultural context. There are three well-cited and similar empirical global culture models in the literature: (Hofstede, 1980; Hofstede, 1991) world-wide 40 country IBM study $(n=116,000)$, (Trompenaars \& Woolliams, 2002) international manager study across 28 countries $(n=15,000)$, and Global Leadership and Organizational Behavior Effectiveness (GLOBE) study (House et al., 2004) of 951 non-multinational organizations (in food processing, financial services, or telecommunication industries), across 62 societies/countries throughout the world. There are alternatives and variations, along with supporters and objectors to the validity of each. According to (Kluckhohn, 1962), cultural models define patterns of basic problems that have consequences for the functioning of groups and individuals, e.g. (a) relation to authority; (b) the conception of self, including ego identity; and (c) primary dilemmas of conflict and dealing with them. These basic problems can be recognized in the (Hofstede, 2001) and (Hofstede \& Hofstede, 2005) model, and have been found in other studies, such as those by (Trompenaars \& Woolliams, 2002), and the recent GLOBE study by (House et al., 2004). While afore mentioned models focus on cross cultural national perspective, cultural impact on learning within a country or among distinct ethnic groups has largely been ignored by researchers.

So far, there have only been a comparatively small number of studies analyzing learning styles across cultures. While these studies have used various conceptualizations of learning styles (see, for example, (Jackson, 1995; Ramburuth \& McCormick, 2001; Manikutty, Anuradha, \& Hansen, 2007; You \& Jia, 2008), the majority of investigations into how the learning style preferred by individuals varies with the individual's cultural background has used the classification suggested by (Kolb, 1984). These include the studies by (Auyeung \& Sands, 1996), (Barmeyer, 2004), (Hanisch, 2003), (Jaju, Kwak, \& Zinkhan, 2002), (Lam, 1998), and (McKee, Mock, \& Ruud, 1992).

According to (Chang et al., 2011), cross-cultural research in the past fifty years has primarily focused on differences between Eastern and Western cultures. He further states that some scholars believe that cultural learning differences may be responses to the physical environment in the areas in which a culture was initially founded. Eastern cultures seem to be more collectivistic, interdependent, hierarchical, and dialectic. On the other hand, Western cultures are more individualistic, independent, egalitarian and less context dependent. Similarly, according to (Joy \& Kolb, 2009), in organizations with workers from various cultures appear to display different styles of work and problem solving.

In an attempt to find more relevant literature, the focus was shifted toward studies that measured either culture or learning style using proven models (yet included both theories). According to (Samovar, 1981), a simple process of logical analysis applied to the semantics of the terms 'culture' and 'learning style', leaves little room for doubt on the 
existence of cultural influences in the development of individual learning preferences. He further argues that it is due to culture which influences the way we communicate, interact, perceive, organize and process information, and solve problems. Similarly, (Terpstra \& David, 1985), stipulate that the way we form 'mental categories' and retrieve them in order to create patterns which allow us to generate new knowledge by means of previously acquired knowledge. (Grasha, 1990, p. 26) defines learning styles with reference to student learning as "the preferences students have for thinking, relating to others, and particular types of classroom environments and experiences". Multiple studies of crosscultural learning and ELT support the notion that learning styles may vary from one culture to another, see (Algee \& Bowers, 1993), (Hanpol, 1987), (Hayes \& Allinson, 1988), (Hoppe, 1990), (Katz, 1988), (McMurray, 1998), (Rhodes, 1990), (Ruksasuk, 2000), and (SANDERS \& Sanders, 1988). These studies point the way for future research to identify the specific relationships between learning dimensions and various aspects of international cultures.

In a seminal study that impacted the way psychologists accounted for cultural differences in patterns of learning and teaching, (Rogoff, 1991, p.7) proposed that culture, as learned by the child from family, community, and school has a strong influence on the cognitive activities practiced by members. Her outlook to children was as:

"apprentices in thinking, active in their efforts to learn from observing and participating with peers and more skilled members of their society, developing skills to handle culturally defined problems with available tools, and building from these givens to construct new solutions within the context of sociocultural activity"

Rogoff provided evidence that American students were influenced by Piaget's theory of meaningful learning which placed a high value on the skill of 'understanding' educational materials. Within the same study, Rogoff also demonstrated how Chinese students, being influenced by a Mandarin educational culture, showed a preference toward the skill of 'memorizing' educational materials. The results of her study showed that culture has a strong effect on individuals' preferences for the ways they like to learn new material and process new information.

All students who enter university have knowledge acquisition and learning behaviors. These have been shaped by students' personalities, abilities, and previous educational experiences. (Ballard, 1997) state that different cultural traditions stipulate different attitudes to knowledge that vary significantly among different cultures. (Pratt, 1992) argues that learning styles may vary from culture to culture. A modest body of the recent interdisciplinary research in this area aims to enhance our understanding of how learning styles or approaches vary across cultures, see, for instance, (Bates, Bentler, \& Thompson, 1979), (De Vita, 2001), (Ramburuth \& McCormick, 2001), (Barron \& Arcodia, 2002), (Morse, 2003), and (Evans, Cools, \& Charlesworth, 2010).

According to (Felder \& Brent, 2005), experts have also identified distinct preferences for learning by considering the process on two levels: 1) how information is received; and 2) how it is processed. Specifically, students are viewed as having a preference for either a concrete experience, or for more abstract concepts in terms of gaining information, which substantiates Kolb's experiential learning theory. With regard to information processing, some prefer active experimentation, while others work better with reflective observation. These learning abilities and likely their reinforcement have taken place in the context of a culture. (Swanson, 1995) rightly states that while research and literature have examined learning styles and preferences across a number of disciplines, little attention has been placed on the culturally derived aspects, especially in post-secondary education. Those studies that have examined this feature, however, suggest there are in fact culturally based variations.

(Raza, Murad, \& Kayani, 2010) conducted a study of the learning climate for managerial knowledge at a private sector business school located in Lahore, Pakistan. They found that culture and environment are the most important dimensions of the learning climate for managerial knowledge at the business school. This partially shows that usefulness of the learning climate is closely linked to the different socio-cultural dimensions interacting with each other. It is pertinent to mention that only a handful of studies have been conducted in Pakistan in ascertaining learning styles with respect to gender and other economic variables, but without cultural context. Although many studies have studied the impact of culture on learning styles preferences among countries, but we have yet to come across a study which involved specifically measuring the impact of culture on learning style preferences among distinct ethnic groups within a particular country. Thus, a huge gap seems to exist in multicultural learning field, and it is imperative that in order to completely understand multicultural learning in a diverse environment, one must start at ethnic level.

\section{Recommendations and Conclusion}

As a first step, existing curriculum must be designed to be commensurate with existing culture in order for students to study within a familiar context. As an example, authors of management books should make effort to incorporate 
contextual based case studies and quote examples of local companies. A Pakistani or Indian student may feel out of place while analyzing case study of Boeing Corporation, instead, analyzing a company within the same cultural context may become relativity easier to comprehend.

Secondly, analyzing learning styles of various ethnic groups may be more fruitful as opposed to relying on national culture. The surrounding environment and cultural factors impact the way we learn. Developing countries form a good example where students have limited resources while studying in a sub-standard academic environment without a school building. Comparing with the environment provided by developed countries, it would be same as comparing apples to oranges. Thus, basic concepts being universal in nature must be disseminated to students within the native ethnic context in order to promote an effective learning environment.

Thirdly, while majority of the curricula is in English language, students belonging to a multilingual background must suffice to the English language requirement. At the same time, this may conflict directly with the prevailing culture where emphasis is given to national or regional languages. A way forward in terms of national policy making would prove beneficial.

Thus, culture and learning are entwined and form a symbiotic relationship. Having said that, management curricula as well as instructional and learning environment must conform to this irreplaceable relationship to the root level in order to positively aide the ever changing global world.

\section{References}

Algee, A., \& Bowers, W. (1993). A Comparison of Learning Styles between Asian and American Seminary Students. Research Methodology. Retrieved from http://eric.ed.gov/ERICWebPortal/recordDetail?accno=ED360887

Auyeung, P., \& Sands, J. (1996). A cross cultural study of the learning style of accounting students. Accounting \& Finance, 36(2), 261274.

Ballard, B. (1997). Teaching international students: A brief guide for lecturers and supervisors. IDP Education Australia.

Barmeyer, C. I. (2004). Learning styles and their impact on cross-cultural training: An international comparison in France, Germany and Quebec. International Journal of Intercultural Relations, 28(6), 577-594.

Barron, P. E., \& Arcodia, C. (2002). Linking learning style preferences and ethnicity: International students studying hospitality and tourism management in Australia. Journal of Hospitality, Leisure, Sport and Tourism Education, 1(2).

Baskerville, R. F. (2003). Hofstede never studied culture. Accounting, Organizations and Society, 28(1), 1-14.

Bates, J. E., Bentler, P. M., \& Thompson, S. K. (1979). Gender-deviant boys compared with normal and clinical control boys. Journal of Abnormal Child Psychology, 7(3), 243-259.

Benedict, R. (1946). The Sword and the Chrysanthemum. Boston: Houghton Mifflin.

Cambridge, J. (2006). Special Issue: The private education sector: towards a reconceptualisation Research degree abstracts. Compare, 36(4).

Chang, L., Mak, M. C. K., Li, T., Wu, B. P., Chen, B. B., \& Lu, H. J. (2011). Cultural adaptations to environmental variability: An evolutionary account of East-West differences. Educational Psychology Review, 23(1), 99-129.

Chapman, A. (2006). Diagrams of Kolb's Learning Styles. Kolb learning styles.

De Vita, G. (2001). Learning styles, culture and inclusive instruction in the multicultural classroom: A business and management perspective. Innovations in Education and Teaching International, 38(2), 165-174.

Evans, C., Cools, E., \& Charlesworth, Z. M. (2010). Learning in higher education - how cognitive and learning styles matter. Teaching in Higher Education, 15(4), 467-478. doi:10.1080/13562517.2010.493353

Felder, R. M., \& Brent, R. (2005). Understanding student differences. Journal of Engineering Education, 94(1), 57-72.

Grasha, A. F. (1990). Using traditional versus naturalistic approaches to assessing learning styles in college teaching. Journal on excellence in college teaching, 1, 23-38.

Gu, Q., \& Maley, A. (2008). Changing places: A study of Chinese students in the UK. Language and Intercultural Communication, 8(4), 224-245.

Hall, E. T. (1977). Beyond Culture. Anchor.

Hanisch, D. A. (2003). Managementtraining in China. Lang.

Hanpol, T. (1987). The relationships among learning style, perceived teaching style, and achievement in a Thai university course. University of Missouri-Columbia.

Hayes, J., \& Allinson, C. W. (1988). Cultural differences in the learning styles of managers. Management International Review, 75-80.

Hofstede, G. (1980). Culture and organizations. International Studies of Management \& Organization, 10(4), 15-41.

Hofstede, G. (1986). No Title. International Journal of Intercultural Relations, $10((3)), 301$.

Hofstede, G. (1991). Organizations and Cultures: Software of the Mind. McGraw-Hill, New York (p. 279$).$

Hofstede, G. (2001). Hofstede, (1997).

Hofstede, G., \& Hofstede, G. J. (2005). Cultures and Organizations: Software of the. Mind. New York: McGraw-Hill.

Hooker, J. (2003). Working across cultures. Stanford University Press.

Hoppe, M. H. (1990). A comparative study of country elites: International differences in work-related values and learning and their 
implications for management training and development. University of North Carolina at Chapel Hill.

House, R. J., Hanges, P. J., Javidan, M., Dorfman, P. W., \& Gupta, V. (2004). Culture, leadership, and organizations. Sage Publications London.

Jackson, T. (1995). European management learning: A cross-cultural interpretation of Kolb's learning cycle. Journal of Management Development, 14(6), 42-50.

Jaju, A., Kwak, H., \& Zinkhan, G. M. (2002). Learning styles of undergraduate business students: A cross-cultural comparison between the US, India, and Korea. Marketing Education Review, 12(2), 49-62.

Joy, S., \& Kolb, D. a. (2009). Are there cultural differences in learning style? International Journal of Intercultural Relations, 33(1), 6985. doi:10.1016/j.jijintrel.2008.11.002

Katz, N. (1988). Individual learning style. Journal of Cross-Cultural Psychology, 19(3), 361-379.

Kennedy, P. (2002). Learning cultures and learning styles: myth-understandings about adult (Hong Kong) Chinese learners. International Journal of Lifelong Education, 21(5), 430-445. doi:10.1080/02601370210156745

Kingston, E., \& Forland, H. (2004). Bridging the gap in expectations between international students and academic staff.

Kluckhohn, C. (1962). Culture and behavior.

Kolb, D. (1984). Experiential learning: Experience as the source of learning and development (Vol. 1). Englewood Cliffs, NJ: Prentice Hall.

Lam, S. S. K. (1998). Organizational performance and learning styles in Hong Kong. The Journal of social psychology, 138(3), 401-402.

Manikutty, S., Anuradha, N. S., \& Hansen, K. (2007). Does culture influence learning styles in higher education? International Journal of Learning and Change, 2(1), 70-87.

Markus, H. R., \& Kitayama, S. (1991). Culture and the self: Implications for cognition, emotion, and motivation. Psychological Review; Psychological ..., 98(2), 224.

McKee, T. E., Mock, T. J., \& Ruud, T. F. (1992). A comparison of Norwegian and United States accounting students' learning style preferences. Accounting Education, 1(4), 321-341.

McMurray, D. (1998). Learning styles and organizational behavior in Japanese EFL classrooms. Journal of Fukui Prefectural University, 13, 29-45.

Mitchell, B. S., Xu, Q., Jin, L., Patten, D., \& Gouldsborough, I. (2009). A cross-cultural comparison of anatomy learning: Learning styles and strategies. Anatomical sciences education, 2(2), 49-60.

Mitsis, A., \& Foley, P. W. (2009). Do Business Students' Culturally Anchored Values Shape Student-Driven or Teacher-Driven Learning Style Preferences? Journal of Marketing Education, 31(3), 240-252.

Morse, K. (2003). Does one size fit all? Exploring asynchronous learning in a multicultural environment. Journal of Asynchronous Learning Networks, 7(1), 37-55.

Moskvina, V., Kozhevnikov, M., Rayner, S., \& Cools, E. (2011). Determining cognitive styles: Historical perspective and directions for further research. Style differences in cognition, learning, and management: Theory, research and practice, 19-31.

Pratt, D. D. (1992). Chinese conceptions of learning and teaching: A Westerner's attempt at understanding. International Journal of Lifelong Education, 11(4), 301-319.

Ramburuth, P., \& McCormick, J. (2001). Learning diversity in higher education: A comparative study of Asian international and Australian students. Higher Education, 42(3), 333-350.

Raza, A., Murad, H., \& Kayani, A. (2010). Perceptions of MBA students towards learning climate for managerial knowledge: A study of business school in Lahore. Multicultural Education \& Technology Journal, 4(4), 251-260. doi:10.1108/17504971011087540

Rhodes, R. W. (1990). Measurements of Navajo and Hopi Brain Dominance and Learning Styles. Journal of American Indian Education, 29(3), 29-40.

Rogoff, B. (1991). Apprenticeship in Thinking: Cognitive Development in Social Context. Oxford University Press, USA.

Ruksasuk, N. (2000). Effects of learning styles and participatory interaction modes on achievement of Thai students involved in webbased instruction in library and information science distance education. University of Pittsburgh.

Samovar, L. (1981). Understanding intercultural communication.

SANDERS, A. G., \& Sanders, A. G. (1988). Learning styles in Melanesia: Toward the use and implications of Kolb's model for national translator training. Dissertation.

Shi, Z. (2004). Essentialism, anti-essentialism and pedagogical studies in China. Educational Research, 25(1), 11-20.

Signorini, P., Wiesemes, R., \& Murphy, R. (2009). Developing alternative frameworks for exploring intercultural learning: a critique of Hofstede's cultural difference model. Teaching in Higher Education, 14(3), 253-264.

Spencer-Oatey, H. (2000). Culturally speaking: Managing rapport through talk across cultures. Continuum.

Swanson, L. (1995). Learning Styles: A Review of the Literature. Retrieved from http://eric.ed.gov/ERICWebPortal/record Detail?accno $=$ ED387067

Terpstra, V., \& David, K. H. (1985). The cultural environment of international business. South-Western Pub. Co.

Triandis, H. C. (1994). Culture and social behavior. Mcgraw-Hill Book Company.

Trompenaars, F., \& Woolliams, P. (2002). A new framework for managing change across cultures. Journal of change management, 3(4), 361-375. doi:10.1080/714023847

Williamson, D. (2002). Forward from a critique of Hofstede's model of national culture. Human Relations, 55(11), $1373-1395$.

You, Z., \& Jia, F. (2008). Do they learn differently? An investigation of the pre-service teachers from US and China. Teaching and Teacher education, 24(4), 836-845. 